\title{
8
}

\section{LIE TO LIVE}

\section{The production of a faked reality as an existential function of Putin's regime}

\author{
Anna Zafesova
}

\section{The need to be believed}

Once upon a time, a delegation of the Italian Communist Party went to Moscow and, as it was customary at the time, the Italian comrades were to meet the Soviet comrades. They were received by comrade Boris Ponomariov, the head of the Foreign department of the Central Committee of the Communist party of the Soviet Union, and they told him about their concern about the Soviet invasion of Afghanistan. They told him it was really difficult, nearly impossible, for them to justify this invasion before their followers and voters, that it was a brutal and completely counterproductive move. In response, comrade Ponomariov repeated to them all the explanations of the Soviet propaganda, such as the need to respond to a call of international solidarity from Kabul, and the urge to occupy Afghanistan before the US did. The Italian comrades expressed their disappointment to be treated like fools and objected to the obvious piece of propaganda. At that point, Ponomariov looked them intensely in the eyes and said gravely: "You must believe us."1

More than 30 years later, in the autumn of 2014, the Italian government made an attempt to bring Vladimir Putin to negotiate the Ukrainian crisis with his Westem counterparts, inviting him to an international summit in Milan. As a former East German citizen and somebody who learned Russian at school, Angela Merkel was chosen as the chief negotiator for the West. Mrs. Merkel waited for Putin almost until midnight. The Russian president was late as usual: he went to Belgrade, where he was welcomed with a military parade, and he was still awaited for a truffle dinner at the country villa of Silvio Berlusconi (Yardley and Herszenhorn 2014). When he finally appeared, Mrs. Merkel, a little bit annoyed, asked him to expose his 'real' reasons and requests about Crimea and Ukraine (Buckley et al. 2015). Putin, at 2 a.m., being alone with the most powerful woman in Europe, a unique opportunity to negotiate without witnesses and restraints, started again 
to expose his usual propaganda: the 'Nazi coup' in Kiev backed by the West, the danger to the Russian-speaking population in Crimea, and so on (Dempsey 2014). He did not ask for any realpolitik concessions, for example, to exchange the recognition of Crimea and the Donbass as Russian territories for some guarantees against Russian missiles aiming at Europe, or oil and gas discounts, or other potentially tradable issues. Putin was in need of something entirely different: "You have to admit we are right," he told the chancellor. The two leaders had more or less the same conversation again a month later, at the G20 summit in Brisbane (Barkin and Rinke 2014). Then, Angela Merkel called Barack Obama and told him that it is impossible to negotiate with Putin because he "lives in another world," as she put it (Baker 2014).

These two little true stories help to define better the problems we are facing in our newsrooms. There are many recent researches about the strategy and the tactics of the fake news interference inspired by Russians in the Western politics and media environment, which present them as a tool of a 'hybrid war' against the West; something invented and promoted specifically to undermine the enemy. For fake news we usually mean altered or completely wrong facts, and we suppose that people who are spreading them do so intentionally. In other words, they lie and they know it. From the fact-checker's point of view, it is quite simple: you consider a statement, you research it, you find out it is a fake, you tell it, and people open their eyes. The reality is much more complex, as we are starting to find out now that fake news is becoming an issue of concern in the West. We Westerners have our own trolls, both on payroll of some political forces and volunteers, and while they can be linked in some ways to their Moscow colleagues, they are an expression of our homegrown disease and vulnerabilities.

\section{Telling the truth from lies}

When we are speaking about Russia, however, we are dealing with something we are not prepared for: an entire alternative reality, for which being believed and promoting the regime's very own different truth is one of the main goals, one of the tools of survival. The fake news Moscow's agents are spreading in the West is not a byproduct of Putin's regime; rather, it is the main staple Russia produces and consumes. The main target of the faked picture are not the Westerners, but Russians themselves, even the same members of the power system that produces it. As Dr. House would say, everybody lies: to their voters, to their diplomatic counterparts, to the Western public, but first of all to themselves. Some of them, sometimes, know they are lying: somebody obviously knew the truth about the Malaysian Boeing, ${ }^{2}$ for example, about who shot it down and how. But a lot of opinion makers - Russian journalists, Duma members, diplomats etc. - do believe what they are saying, at least to some degree. For them, fake news is not fake at all. Instead, they think and affirm that Western information is entirely and intentionally faked, or at least biased. The lies they are telling to the world are the same they are telling to themselves. In a way, they are not lying: they may be wrong, but they think they are right. 
Sometimes we can doubt that even Vladimir Putin can always tell the truth from the false: when he showed Oliver Stone on his phone a video of a Russian raid in Syria that later was revealed by the fact-checkers as being a footage of an American raid, ${ }^{3}$ or when he cited as a crucial witness for the Russian version of the Malaysian Boeing disaster a "Spanish air traffic controller," a fake Twitter account that at the time of the interview was already debunked as fake (Schreck 2018), was he consciously lying to the American filmmaker, or was he an unconscious victim of his own masters of fakes? And who was responsible: the Minister of Defense Sergey Shoigu? Some smart people from the army's press service? Some trolls from the St Petersburg 'factory of trolls' created by Evgeny Prigozhin, the so-called 'Putin's cook'? Did Putin just see the video on the web? And how do we have to deal with it? Must we consider a fake statement from the Russian president that Crimea was not annexed by Moscow but 'reunited' with its homeland (Golubeva, Chernous, Ehrman 2019)? The journalists of free media in a world of free speech may have a problem reporting statements of propaganda without commenting on them, although we also cannot just call a head of a foreign state a liar. But, if we explain that it's just his own opinion, are we giving a lie a more honorable status? Do we need to stop interviewing Russian officials so that we do not help them spread fake news? Would it be correct to object to things they are telling us without forgetting the rules of the objective interview? How do you quote somebody who is part of a system in which the main product is fake news, in a way the crucial exporting Russian industry sector?

But the relationship of the Russian - and before, of the Soviet - regime with the truth is not only its beating heart and its strongest weapon; it is also its weakest point. The Soviet Union collapsed when it became impossible not to face the obvious truth of its failure. It is a system without negative feedback: if you're not allowing the existence of a truth that contradicts the official one, if sticking to the right truth becomes a matter of loyalty, and career, for the members of the establishment as well as for the ordinary people, then the very meaning of the fake disappears. This self-destructive behaviour was most obvious during the Chernobyl disaster, for example, when the long habit of hiding unpleasant truths from highranking officials delayed rescue operations in the affected area and put millions of Soviet and Western citizens in danger. The truth about Chernobyl, mostly revealed in the following months by increasingly free press of the perestroika, was a relevant component of the loss of trust in the regime, and it is really odd to see that, even more than 30 years later, the Russian officials can still become angry at the critical depiction of the Chernobyl incident in the HBO series (Meduza 2019), considering this TV fiction as yet another attack on contemporary Russia, which wants to identify itself with the late Soviet Union rather than see it as belonging to the past.

Another example of this attitude to defend the one and only official truth as a political weapon is President Putin's campaign to "defend the truth on the Second World War," which was even included in the amendments of the new version of the Constitution (Interfax 2020). Russian leadership sees the imposition of its rhetoric on Moscow's special rights as one of the winners in the war as a legitimisation 
of its own ambitions to former Soviet zones of influence, and wants to simply ban any theories that dismantle this narrative, like the resolution of the European Parliament on the 80th anniversary of the beginning of WWII (European Parliament 2019). Again, it is very difficult to understand how much the Kremlin is manipulating the historical truth and to what extent Putin and most of his fellow citizens truly believe something they were taught for half a century.

\section{Truth as a prized asset}

The truth in the Soviet Union was something of a privilege, reserved to the happy few: even Mikhail Gorbachev was absolutely convinced that the Katyn massacre was perpetrated by the Nazis, until his chief of staff Valery Boldin showed him the top secret file. The legend that newly sworn US presidents receive a thick file with the ultimate truths - who shot JFK, were there really aliens at Roswell, and is Elvis still alive - was true in the Soviet Union. Gorbachev, the first and last Soviet president, already the Secretary General of the one and only ruling party, the leader of the country, the plenipotentiary who went to negotiate the end of the nuclear threat with US presidents, even he was ignoring a lot of hidden truths (Taubman 2018), included the Katyn reports and even the secret protocols on the partition of Europe signed together with the Molotov-Ribbentrop Pact. Who did know them? Boldin? The archive employees? High-ranking KGB people? Not even them, as it seems Vladimir Kriuchkov, in his very first days as KGB chairman, launched an inquiry on the 'real' state of things in the country, asserting after his mentor Yuri Andropov that "We ignore the country we live in" (Bondarenko 2004). Later, in August 1991, both Boldin and Kriuchkov became leaders of a doomed hardliners' coup against Gorbachev, ${ }^{4}$ which ultimately led to the collapse of the Soviet Union instead of saving it: it seems that they were not so well informed after all.

As the abovementioned examples from Soviet history show, when lying is systematic within an authoritarian regime, lies become more than lies - to stay in power the removal of truth is necessary, and the same is true for contemporary Russia, which becomes more and more like a late-Soviet regime, rather than a postSoviet one. People inside the system, from the lower levels up, are not encouraged to tell the truth to their superiors: they risk being dismissed and substituted with plenty of officials ready to stick with the desired truth in exchange for the benefits of being a high-ranking member of the regime's nomenklatura. The sanctions imposed by the West against the more prominent among Putin's oligarchs, businessmen, and opinion-makers, were in some way an attempt to force the Kremlin to face the truth, to change its mind about its own power and impunity, to see the limits of its narrative about Russia "rising from its knees" (Manaeva 2019), and the partial failure of these sanctions derives from a system where acknowledging a truth is equal to failure. The side-effect of this mindset is that the system is gradually cleared of the most bright people, i.e. those capable of critical and analytical thinking, and then it lacks the resources to correct the mistakes, which is the first rule of a functioning system, and the first and only condition to survive in the long 
term. We see that the priority of Russian politics is not to achieve concrete goals of any kind - we saw it in Ukraine and in Syria, two wars that are very expensive for the Kremlin from any point of view -, but rather to impose its own truth, to show they were right: defining reality through an official narrative is something that is seen as a source of legitimisation.

One of the most beloved taglines for Russian nationalists is 'Truth is with us', 'Our strength lies in the truth'. The main Soviet newspaper was even called Pravdathe truth, nothing less - while the greatest dissident to challenge the regime, Alexandr Solzhenitsyn, gave one of his political manifestos the title Live Not By Lies (Solzhenitsyn 1974). Having access to an alternative version of the events, which often meant knowing the truth, was something thousands of Soviet citizens were searching for, listening to Western radio broadcasts or reading banned books in the samizdat network. In a way, the fight between the regime and its adversaries, in USSR and abroad, had at its heart the collision between two alternative versions of reality, the clash between truth and false, and hiding the truth was one of the main activities of the repressive branches of the government. The Communist regime collapsed when the truth about it was gradually revealed, when the perception of a faked history, faked success, faked superiority, of a country-sized myth, became widespread, especially when confronted with the much more easily available information about life in the Western countries.

The problem in the Soviet Union was the censorship, the physical unavailability of the truth, which was the most prized and hard to find in the Soviet world of perennial shortages of anything. Having the truth on your side was seen as quintessential to win. Starting with a president who proudly described himself as 'pragmatic', in 20 years Putin's leadership evolved into a quasi-Soviet regime which feeds on ideology and assertions, almost religious in their being undebatable. The current Russian regime uses the old tools of propaganda and censorship together with a very modern and smart implementation of the contemporary tools of media manipulation, including television and social networks (Pomerantsev 2019; 2015). Information manipulation is a mainly domestic product, whose export is a sideactivity of the government's core business of building a reality that voters would like and vote for.

Under Vladimir Putin, Russian public opinion has been shaped for 20 years to stick with an alternate version of facts concerning the Soviet and post-Soviet history, which at some point also became a diplomatic issue. A case in point was the short-lived Commission in charge of fighting the 'distortions' of the history of the Second World War, ${ }^{5}$ founded by the Russian government ${ }^{6}$ to impose its own vision internationally in order to justify Moscow's claims to control former Soviet territories and parts of Eastern Europe, something hardly possible once the Red Army was considered an occupation rather than liberation force. Something, again, that a wide majority of Russians, voters and politicians alike still believe, considering it a truth quintessential to assert the 'greatness' of their country. Putin's obsession with the annual Victory parade, which the Kremlin was reluctant to postpone even in the middle of the Covid-19 pandemic, has transformed it into 
one of the main moments of the political year in Russia, and the list of the preferences for the foreign leaders depends greatly on the ones who accepted the invitation to join the show in the Red Square (and the ones who didn't). These differences in the interpretation of the past (and of the present), eventually, have produced a diplomatic stall in the relations between Russia and most Western diplomacies: it is nearly impossible to have a negotiation or a deal if you disagree even on the basics, and in recent years the role of the head of Russian diplomacy, Sergey Lavrov, has become more of a spokesperson than a Foreign minister, coming to international meeting just to state his government's position and express his indignation towards whomever stays on different grounds.

\section{The truth as a battlefield}

In this Orwellian context where words and narratives take on supreme importance while facts and evidence are devalued, the efforts of opposition leaders, first of all Alexey Navalny, are concentrated on the demolition of the faked version of reality offered by the regime. Navalny is the most vivid example of this battle line between false and true: his main activity is the debunking of the propaganda myths and the spreading of revelations about corruption and illicit conduct of the members of the power elite in Russia. Born as a 'classical' politician, an activist of the then parliamentary party Yabloko, he later became a blogger, then went offline for some months during the street protests in the winter of 2011-2012. He has emerged again in the last four years as the founder and head of something that we can call a sort of opposition media holding; ${ }^{7}$ an alternative television show working on the YouTube platform, with even a weekly news broadcast where the opposition leader acts as an anchorman, telling people news they wouldn't hear in the official media. His 'offline' projects - the Anti-Corruption Foundation ${ }^{8}$ and the party Russia of the Future - would not exist without this media communication, which to some extent is (at least in present Russia) its main goal.

The battle to impose its own truth and hold the monopoly on its own version of the reality is still central to the survival of Putin's power in the Kremlin, as it was in the USSR. But there are two substantial differences. The first one is that Russia is now formally a democracy and it holds regular elections. Rigged, manipulated, or forbidden to the opposition, the vote is still something to conquer, as the source of the 20 -year-long reign of Putin was in the first place his overwhelming popularity, obtained in an undisputed context of propaganda and censorship, but still authentic. Putin's Kremlin is eager to be recognised in the West, Putin's oligarchs want to live, shop, and invest in the West, so the option of becoming a closed totalitarian regime, like the Soviet Union or contemporary North Korea, is not attractive to the leader, nor to his supporters. In a system that somebody called a 'managed democracy', or an 'illiberal democracy', the carrot is more important than the stick, and you have to convince - even by deception - your voters, instead of just threatening them. We saw Putin bringing the media under his control, especially television, much earlier than the oil assets: his rule would be impossible without the monopoly on the news, including faked and manipulated news. 
The second difference, which Russia shares with the Western world, is that today a lot of people, the so called 'ordinary people' - which means readers and voters - refuse the truth even when confronted with it. The problem in contemporary Russia, and now also in the West, is that all the facts are readily available, at least on the web, but people do not want to look for them. Instead, they search for comfortable lies. The perestroika was, in a way, an eye-opening political process, and both in Russia and in the West this moment of revelation was seen as crucial and self-sufficient: once you saw the truth, everything else would work in the right way. This magic does not work anymore. If we look closer at the discontent of the Russian public, which has become widespread in the last two years (Kolesnikov and Volkov 2020), we can see that there is a share of voters who would desire a shift towards the Western standards of democracy - freedom of speech and assembly, free elections, and rule of law. This desire is increasing within the society and it has been expressed mainly by the most wealthy part of the middle class, the intellectuals, the youngest generations of westernised Russians. During the street protest of the 2011-2012 Vladislav Surkov, Putin's ideologist, called the people belonging to those groups "angry urban communities" (Earl 2011). These "angry urban' young people are growing in numbers, because of a natural generational turnover, but also because they don't see many opportunities in the increasingly conservative Russian society. They are mostly immune to the language and to the cultural codes Putin shares with their parents, they have not experienced the shock of the collapse of the Soviet Union, and they are not susceptible to the narrative that 'anything is better than going back to the '90s'. They don't watch TV, they are digital natives, and Internet taught them not to trust anything and anybody, at least not unconditionally. They are the Millennials that we have recently seen leading protests against unfair elections and unjustified arrests, searching and spreading alternative information on the web. We saw them also becoming the main targets of the police and of judiciary repression (Dixon 2020).

Other Russians, the majority, just protest against widespread poverty, corruption, and other social issues, without a clear political programme they would trust and support. But reading on social media, for now one of the few measurement tools of a submerged discontent in Russia, you can see also a lot of people violently criticising Putin for not being Putin anymore, willing for a return of a paternalist and powerful national leader - in other words, willing to have back the narrative of the 'Russia great again' that they have started to perceive as fake. They do not like the way Putin and his court are managing the reality they live in, but they still stick with the myths and narratives the government has created in the past years, included the one of Western malevolence and interference. Essentially, they are asking to remain inside the fake propaganda picture, even when confronted with facts.

We see the same weakness of the facts in Western public opinion. Stating what is considered as a fact did not work with the Anti-Vax movement, for example, and it doesn't work well in the debates on the economy - as a former vice minister of the Italian populist Five Star Movement put it when confronted with risks of inflation and growing debt burden by a professional economist, "It's your words," 
cancelling with one sentence years of research and empirical experience on a highly specialistic field. ${ }^{9}$ The psychological and political mechanism of Western populists and sovereignists is similar to that adopted by the Russian regime: you have to create an altemate reality, to leave rational grounds and make potential voters believe it, because otherwise it would be impossible to play on the adversary's ground where you can differ in opinions or interests you advocate, but not on the basic principles of what is rational and possible.

This brings us to the possible solution of the fake news problem, which is not only a problem for journalists and politicians. In the first Cold War, the goal was to let the truth about the regime slip across the border: the fake reality of Communism would shatter in pieces and the 'evil empire' would fall. It worked. During the new Cold War of fake news, we have to fight simultaneously on two fronts, because we have the same problem at home. We are finding out that the immune defenses of European and Western democracies are weaker than we had thought and the vaccination must come from the school system, from cultural institutions, from governments. But these are all long-term processes while we are dealing with the news, so we have to respond quickly. What do we have to do as journalists? We have to do our job: verifying our sources, crosschecking information, trying to be impartial, and using less adjectives and more data. It can sound too simple, but if in a lot of Western countries we are facing the risk of a potential interference of the Russian official and unofficial media actors aiming at conquering a share of the public, and the risk of domestic political forces using the same method (aided or not by Moscow), it is because we didn't do our job well enough. Legal tools to stop possible Russian interferences are needed, to be applied by governments, media outlets, and social networks, but they will be not enough without a solid counter-narrative. Again, during the Cold War Moscow invested a lot in the propaganda, sustaining news outlets like Novosti agency (of which the RIA Novosti is the heir) or Communist newspapers, courting influential opinion-makers (writers, filmmakers, painters) and moving puppet parties, movements, and NGOs. But the Soviet propaganda efforts were efficiently blocked by a widespread information on the crimes of the Communist regime and on the hard life most of the Soviet citizens led, which resulted in appealing to only a minority of Western public opinion.

Russia has this strange role of being a sort of mythical place to part of the Western audience, something to look at as an alternative to the existing order, but from a distance (Applebaum 2019). Today the pro-Russian public in the West is no longer a network of left-wing sympathisers; Putin's supporters in the West mainly support right-wing parties and movements. Instead of a realm of equality, welfare, and wellbeing for the ordinary people, Russia is perceived today as a rich, powerful nation, invulnerable to the problems of the contemporary world - globalisation, migration, and secularisation. Instead of being seen as the radiant future of Communism, Putin's Russia is now perceived by many Westerners as a heaven where the good old past still survives, where there are no immigrants, LGBT people, 
pacifists, feminists, and environmental activists; a country which is faithful to the 'traditional Christian values', with white males still firmly in control of their families, and clear and undisputed hierarchies. Both narratives are nothing more than propaganda myths, or fakes, as they could be called nowadays. The only way to fight them is to tell the truth. Cognitive dissonance is the most powerful weapon against ideology.

\section{What to do? Some final remarks}

Informed people are harder to force into believing without questioning. However, it is hard to see how information, critical analysis, and propaganda interact in a horizontal world, where everybody can create and spread information and opinions. Journalists must convince the public to listen to them because they have an expertise. This is what makes them different, this is what makes them professionals. Even if they do not know everything, they are trained to deal with information and to recognise it as fake or true, and to know whom and how to ask when they do not know something. They have to attract the public's attention on relevant issues; nothing is given anymore as a birthright, journalists of longestablished media outlets are no longer considered as particularly trustworthy. They have to train their readers not to trust anybody blindly, not even journalists. This task requires a good dose of old-school journalism: not infotainment, not partisan spirit, not gossips, not click-baiting. Journalists must use as a rule of thumb - for example, not considering politicians' tweets as news, especially when it comes to the populist and authoritarian ones. Doing this just helps them to reach a larger audience. Media must learn what to tell and what not to tell, not because of a censorship, but to set rules: pulp news, TV shows that rise their ratings by inviting political freaks, fear and hate speech and morbid passion for disasters and catastrophes - it might sound out of fashion, but our media shares the responsibility for the fake news epidemic and we have to acknowledge it. At least in Italy, we do. In a world of perfect journalism, why would people look for fakes and believe them to be true?

What media and journalists must do is not only to debunk, find out, and expose fakes. In this way, they will be only following others' initiative. Speaking of Russia, they have to produce and propose alternative facts and views, to inform, to show different aspects of Russian life. For example, speaking more about the reform of the Russian retirement system or of the healthcare system than about Putin's new car or the last military parade - showing more grim reality and less Kremlin glamour, in other words, to avoid falling for the propaganda that media professionals are supposed to fight against. As hard as this may be, we need to clearly distinguish between fakes and facts, facts and opinions, opinions and propaganda. A clear set of rules for dealing with information must distinguish certified journalists from other media and paramedia producers. We have to be there not only to fight fakes; we need to be there before fakes arrive, and do our job. 


\section{Notes}

1 From a private conversation between the author and one of the members of the delegation, at the time a high-ranking member of the Italian Communist Party (PCI).

2 On 17 July 2014, a Boeing-777 of Malaysian Airlines was shot down over Donbass while performing a flight from Amsterdam to Kuala Lumpur (MH17). All 283 passengers and 15 crew were killed. The Dutch-led international Joint Investigation Team concluded that the aircraft was downed by a Buk surface-to-air missile fired from the territory controlled by the Russian-backed separatists, been brought and controlled by Russian military from the 53rd Anti-Missile Brigade of the Russian Federation. After years of investigation, the Dutch Public Prosecution Service started a trial hearing in March 2020, with several of the Russian military being charged for the downing of the MH17. The Russian government always denied any responsibility and/or involvement. Moscow didn't offer an alternative explanation. Instead, from the very first hours after the disaster, different officials and commentators suggested a different hypothesis, attributing the guilt to a Ukrainian fight jet, Ukrainian surface-to-air missile, a bomb placed on board, and even a statement that the aircraft was filled with dead bodies by some Western intelligence service which then shot at it to put the blame on Donbass separatists (a plot clearly borrowed from the Sherlock series).

3 See on YouTube the video shared in 2018, 'Vladimir Putin Shows Oliver Stone a Fake Video', www.youtube.com/watch? $\mathrm{v}=-\mathrm{ZGX}$ 9XtPUrw

4 On 18 August 1991, a group of conservative high-ranking Communist Party officials, ministers, and intelligence officers launched a coup against Mikhail Gorbachev and his plan to sign a new Union Treaty that would decentralise power in USSR. The coup's leaders formed a State Committee on the State of Emergency, imprisoned Soviet President Gorbachev in his Crimea dacha, suppressed freedom of speech and gathering, brought tanks into Moscow, and tried to arrest liberal politicians and Russian Federation President Boris Yeltsin. The widespread campaigning of civil resistance in Moscow, led by Yeltsin, and the refusal of special units commanders to assault the Russian Parliament which became the headquarters of the resistance, brought the attempted coup to collapse. Gorbachev returned to Moscow and was reinstated in power on 21 August. The coup discredited the Communist leadership and the Communist party was ontlawed. The coup leaders were arrested. In the three days of turmoil in Moscow most Soviet republics declared independence, and the coup that aimed to save the Soviet Union instead accelerated its collapse, formalised by the Supreme Soviet of the USSR on 26 December 1991.

5 The Presidential Commission of the Russian Federation to Counter Attempts to Falsify History to the Detriment of Russia's Interests was founded by a decree from the then Russian President Dmitry Medvedev in 2009, and included several top-ranking government officials, members of Parliament, military and intelligence officers, and historians heading the State research centres. The Commission's goal was to counteract 'revisionist' attempts from foreign countries and Russian opposition to 're-write' the history of the Second World War, especially in regard to the Soviet role in Eastern Europe. The Commission was disbanded in 2012, but Russian diplomacy continues to vehemently attack any statement which goes against the 'official version' of history.

6 See the official news on the webpage of the Russian President: http://en.kremlin.ru/ events/president/news/4121.

7 Navalny.com, Navalny Live YouTube channel, FBK (Anti-Corruption Foundation) social accounts, and some other online resources are all expressions of the opposition group led by Alexey Navalny. They function both as a political platform and as alternative media outlets which produce documentaries, shows, and news critical of the official propaganda version, with special attention to exposing the corruption of the Russian government and governors. Navalny himself stars in different videos and is the host of a weekly show commenting on the main news, while explaining to his followers how to organise themselves to counteract the wrong-doing he reveals. For further reading and watching, www. navalny.com blog contains all the activities of Alexey Navalny and his allies and links to 
all other resources of the group, which acts only on the web, the last partially free media environment in Russia.

8 This is the website of the Anti-Corruption Foundation: https://fbk.info/english/about/.

9 This is the video of the discussion, broadcasted by a popular TV show on Italian national television. The video of the confrontation between Laura Castelli and Pier Carlo Padoan became viral for its grotesque tone: www.youtube.com $/$ watch?v $=Z 7 f 2 \mathrm{imIR} 6 \mathrm{xI}$.

\section{References}

Applebaum, A. (2019) 'The false romance of Russia', The Atlantic, 12 December 2019, www.theatlantic.com/ideas/archive/2019/12/false-romance-russia/603433/.

Baker, P. (2014) 'Pressure rising as Obama works to rein In Russia', The New York Times, 2 March 2014, www.nytimes.com/2014/03/03/world/europe/pressure-rising-asobama-works-to-rein-in-russia.html?

Barkin, N., A. Rinke (2014) 'Merkel hits diplomatic dead-end with Putin', Reuters, 25 November 2014, www.reuters.com/article/us-ukraine-crisis-germany-insight/merkelhits-diplomatic-dead-end-with-putin-idUSKCN0J91EN20141125.

Bondarenko, A. (2004) 'Vladimir KRYUCHKOV: "I did everything I could to save the power”, Krasnaia Svezda, 28 February 2004, http://old.redstar.ru/2004/02/28_02/5_01. html.

Buckley, N. et al. (2015) 'Battle for Ukraine: How the West lost Putin', Financial Times, 2 February 2015, www.ft.com/content/e3ace220-a252-11e4-9630-00144feab7de.

Dempsey, J. (2014) 'Can Merkel deal with Putin's myths?', Carnegie Europe, 20 October 2014, https://carnegieeurope.eu/strategiceurope/56962.

Dixon, R. (2020) 'They were Russian vegans, environmentalists, antifascists and airsoft players. Then they were accused of terrorism', The Washington Post, 10 February 2020, https://www.washingtonpost.com/world/they-were-russian-vegans-environmentalistsantifascists-and-airsoft-players-then-they-were-accused-of-terrorism/2020/02/10/1197 d95e-4c19-11ea-a4ab-9f389ce8ad30_story.html.

Earl, J. (2011) 'Surkov and Prokhorov spin election', The Moscow Times, 6 December 2011, https://www.themoscowtimes.com/2011/12/06/surkov-and-prokhorov-spinelection-a11270.

European Parliament (2019) Resolution on the Importance of European Remembrance For the Future of Europe, 19 September 2019, www.europarl.europa.eu/doceo/document/ TA-9-2019-0021_EN.html.

Golubeva, A., A. Chernous, G. Ehrman (2019) "'Return" or "power grab"? The crisis in Ukraine in Russian and Ukrainian history textbooks', BBC Russia, 15 March 2019, www.bbc.com/russian/features-47442536.

Interfax (2020), "Putin considered it appropriate to "carefully reflect" the prohibition on falsification of history in the Constitution', 26 February 2020, www.interfax.ru/ russia/ 696798 .

Kolesnikov, A., D. Volkov (2020) 'Russians' growing appetite for change', Carnegie Moscow Center, 30 January 2020, https://carnegie.ru/2020/01/30/russians-growing-appetitefor-change-pub-80926.

Manaeva, N. (2019) 'Kadyrov congratulated Putin on his 20th anniversary: "He has lifted Russia from its knees", Znak, 17 August 2019, www.znak.com/2019-08-17/ kadyrov_pozdravil_putina_s_20_letiem_u_vlasti_on_podnyal_rossiyu_s_kolen.

Meduza (2019) "Illiterate, stupid, uninquiring idiots". HBO's "Chernobyl" miniseries has enraged Russia's state media and pro-Kremlin reporters. Here's why they hate it', 6 June 2019, https://meduza.io/en/slides/illiterate-stupid-uninquiring-idiots. 
Pomerantsev, P. (2015) Nothing Is True and Everything Is Possible: The Surreal Heart of the New Russia, London: Faber \& Faber.

Pomerantsev, P. (2019) This Is Not Propaganda: Adventures in the War Against Reality, London: Faber \& Faber.

Schreck, C. (2018) “"That awkward moment": Putin cited debunked MH17 claims in Oliver Stone interview', Radio Free Europe/Radio Liberty, 5 March 2018, www.rferl.org/a/putindebunked-spanish-air-traffic-controller-claims-oliver-stone-interview/28709936.html.

Solzhenitsyn, A. (1974) Live Not By Lies, 12 February 1974, full text in English available at: https://archive.org/stream/LiveNotByLies/Live\%20Not\%20By\%20Lies_djvu.txt.

Taubman, W. (2018) Gorbachev: His Life and Times, New York: Simon \& Schuster.

Yardley, J., D.M. Herszenhorn (2014) 'Making Merkel wait, finding time for truffles', The New York Times, 17 October 2014, www.nytimes.com/2014/10/18/world/unbowedputin-chews-the-scenery-in-milan.html. 